\title{
Ultrastructural morphogenesis of a virus associated with lymphocystis-like lesions in parore Girella tricuspidata (Kyphosidae: Perciformes)
}

\author{
P. M. Hine ${ }^{1,3, *}$, St. J. Wakefield ${ }^{2}$, G. Mackereth ${ }^{1}$, R. Morrison ${ }^{1}$ \\ ${ }^{1}$ National Centre for Disease Investigation, MAF Operations, Ministry of Agriculture and Forestry, PO Box 40-742, \\ Upper Hutt, New Zealand \\ ${ }^{2}$ School of Medicine, University of Otago, PO Box 7343, Newtown, Wellington, New Zealand \\ ${ }^{3}$ Present address: 73 , rue de la Fée au Bois, Fouras 17450, France
}

\begin{abstract}
The morphogenesis of large icosahedral viruses associated with lymphocystis-like lesions in the skin of parore Girella tricuspidata is described. The electron-lucent perinuclear viromatrix comprised putative DNA with open capsids at the periphery, very large arrays of smooth endoplasmic reticulum (sER), much of it with a reticulated appearance (rsER) or occurring as rows of vesicles. Lysosomes, degenerating mitochondria and virions in various stages of assembly, and paracrystalline arrays were also present. Long electron-dense inclusions (EDIs) with $15 \mathrm{~nm}$ repeating units split terminally and curled to form tubular structures internalising the $15 \mathrm{~nm}$ repeating structures. These tubular structures appeared to form the virion capsids. Large parallel arrays of sER sometimes alternated with aligned arrays of crinkled cisternae along which passed a uniformly wide $(20 \mathrm{~nm})$ thread-like structure. Strings of small vesicles near open capsids may also have been involved in formation of an inner lipid layer. Granules with a fine fibrillar appearance also occurred in the viromatrix, and from the presence of a halo around mature virions it appeared that the fibrils may form a layer around the capsid. The general features of virogenesis of large icosahedral dsDNA viruses, the large amount of ER, particularly rsER and the EDIs, are features of nucleo-cytoplasmic large DNA viruses, rather than features of 1 genus or family.
\end{abstract}

KEY WORDS: Ultrastructure $\cdot$ Lymphocystis $\cdot$ Iridoviruses $\cdot$ Ranaviruses $\cdot$ African swine fever virus $\cdot \mathrm{ASFV}$

\section{INTRODUCTION}

The nucleo-cytoplasmic large DNA viruses (NCLDV) comprise the families Poxviridae, Asfarviridae, Iridoviridae, Phycodnaviridae, Mimiviridae, Ascoviridae and Marseilleviridae (Salas \& Andrés 2013) of the superfamily Megavirales (Clouthier et al. 2013, Piégu et al. 2015). The Iridoviridae comprise 5 genera: Ranavirus infecting poikilothermic vertebrates (Chinchar 2002, Whittington et al. 2010, Chinchar \& Waltzek 2014, Peng et al. 2015); Megalocytivirus (Kurita \& Nakajima 2012) causing systemic infections in fish (Inouye et al. 1992, Subramaniam et al. 2012, Sriwanayos et al. 2013); Lymphocystivirus usually

\footnotetext{
${ }^{*}$ Corresponding author: vinet.hine@orange.fr
}

causing superficial disease (skin, fins) of fish, particularly flatfish (Pleuronectiformes) (Chinchar et al. 2009, Yan et al. 2011); and Iridovirus and Chloriridovirus infecting insects. In general, iridovirids and asfarivirids undergo DNA replication in the nucleus, followed by a second round of cytoplasmic DNA replication in perinuclear, often lucent, viromatrix (Zupanovic et al. 1998, Huang et al. 2006, Chinchar \& Waltzek 2014) or viral factories (Salas \& Andrés 2013) in which scattered icosahedral virions form, that become cytoplasmic paracrystalline arrays of mature virions (Zupanovic et al. 1998, Majji et al. 2006). Virions comprise a dsDNA core, a core shell, an internal lipid layer and an external icosahedral

() The authors 2016. Open Access under Creative Commons by Attribution Licence. Use, distribution and reproduction are unrestricted. Authors and original publication must be credited. 
capsid which, when the virion exits the cell, acquires an external unit membrane from the host cell plasma membrane (Zupanovic et al. 1998, Qin et al. 2001, Salas \& Andrés 2013).

Many reports have described the ultrastructure of iridoviruses, but many only illustrate the virions and their inclusion bodies (e.g. Paperna et al. 1982, Bowden et al. 1995, Colorni \& Diamant 1995, Sudthongkong et al. 2002, Dezfuli et al. 2012, Waltzek et al. 2012). Others report the ultrastructure of the virions (Pearce et al. 1990, Heppell \& Berthiaume 1992). Those that do report other observations (Tanaka et al. 1984, Paperna et al. 1987, Watson et al. 1998, Sudthongkong et al. 2002, Huang et al. 2006, Chinchar et al. 2011, Chinchar \& Waltzek 2014) do not report the process of replication. Most studies are on the late stages of replication because grossly hypertrophied cells have been chosen for study. Studies have shown that when lymphocystis-infected cells lyse, the released virions infect surrounding cells (Spitzer et al. 1982). Choosing peripheral hypertrophied cells and apparently normal skin fibroblasts adjacent to hypertrophied cells has revealed earlier stages of replication, and these are reported here.

\section{MATERIALS AND METHODS}

A parore Girella tricuspidata was caught in the Waitemata Harbour, Auckland, New Zealand. Immediately after capture, pieces of skin at the edges of lymphocystis-like lesions were excised, cut into $\sim 2-$ $4 \mathrm{~mm}^{3}$ pieces, fixed in $2.5 \%$ glutaraldehyde made up with $0.22 \mu \mathrm{m}$ filtered seawater (FSW) for $1 \mathrm{~h}$, washed twice in FSW and stored in FSW for $1 \mathrm{wk}$. They were post-fixed in $1 \% \mathrm{OsO}_{4}$ in $0.1 \mathrm{M}$ cacodylate buffer with $2 \%$ potassium ferrocyanide for $2 \mathrm{~h}$, dehydrated for 10 min each in 15, 30, 50, 70, 80 and $90 \%$ ethanol, then 3 changes for 20 min each in absolute ethanol, $10 \mathrm{~min}$ in propylene oxide, $4 \mathrm{~h}$ in $50 \%$ propylene oxide $+50 \%$ Epon covered, then overnight uncovered, into fresh resin for $8 \mathrm{~h}$, then embedded in fresh resin and heated in an oven at $60^{\circ} \mathrm{C}$. Semithin and then ultrathin sections were then cut, and grids were examined on a Philips CM100 electron microscope.

The term Iridovirus spp. is used here to describe the iridescent viruses of insects. Iridovirid and iridoviruses mean members of the Iridoviridae (sensu stricto) such as Iridovirus spp., Ranavirus spp. and Lymphocystivirus spp. Iridovirus-like means the Iridoviridae (sensu lato) and other dsDNA cytoplasmic viruses, such as those causing viral erythrocytic necrosis (VEN) and African swine fever virus
Table 1. Abbreviations used throughout the text and figure legends

\begin{tabular}{|ll|}
\hline Abbreviation & Definition \\
\hline ASFV & African swine fever virus \\
EDIs & Electron-dense inclusions \\
ER & Endoplasmic reticulum \\
ERGIC & ER Golgi intermediate compartment \\
FV3 & Frog virus 3 \\
LCDV & Lymphocystis disease virus \\
LLB & Lysosome-like bodies \\
NCLDV & Nucleo-cytoplasmic large DNA virus \\
rER & Rough ER \\
rsER & Reticulated smooth ER \\
sER & Smooth ER \\
tER & Thread-like structure \\
TGN & Trans-Golgi network \\
VIB & Viral inclusion body \\
WSIV & White sturgeon iridovirus \\
\hline
\end{tabular}

(ASFV), which was previously placed in the Iridoviridae, but is now the only member of the Asfarviridae. Abbreviations used throughout the text are summarized in Table 1.

\section{RESULTS}

The submitted parore presented with grape-like clusters of hypertrophied cells in the right anterior endodermis, without internal lesions, prompting a presumptive diagnosis of lymphocystis disease. Under the light microscope, infected cells were hypertrophied and surrounded by a weakly basophilic hyaline capsule that increased in width as the infection developed. Initially the cytoplasm was intensely eosinophilic and hyaline in texture, containing peripheral basophilic reticulated inclusions. In some cells, the peripheral inclusion was moderately basophilic and rounded. The nuclei were large and irregular in shape, vesiculated, with prominent heterochromatin, a large nucleolus and without marginated chromatin. As infection appeared to progress, the eosinophilia of the cytoplasm diminished, and the reticulated inclusion also became progressively fainter. Finally the hyaline capsule around the uniformly finely granular and weakly eosinophilic grossly hypertrophied cell broke, releasing the contents. Empty hyaline capsules were frequently infiltrated by an inflammatory exudate of monocytes and eosinophilic granulocytes.

Putative early and middle stages of virogenesis were observed by transmission electron microscopy. Early-stage infections differed from middle-stage 


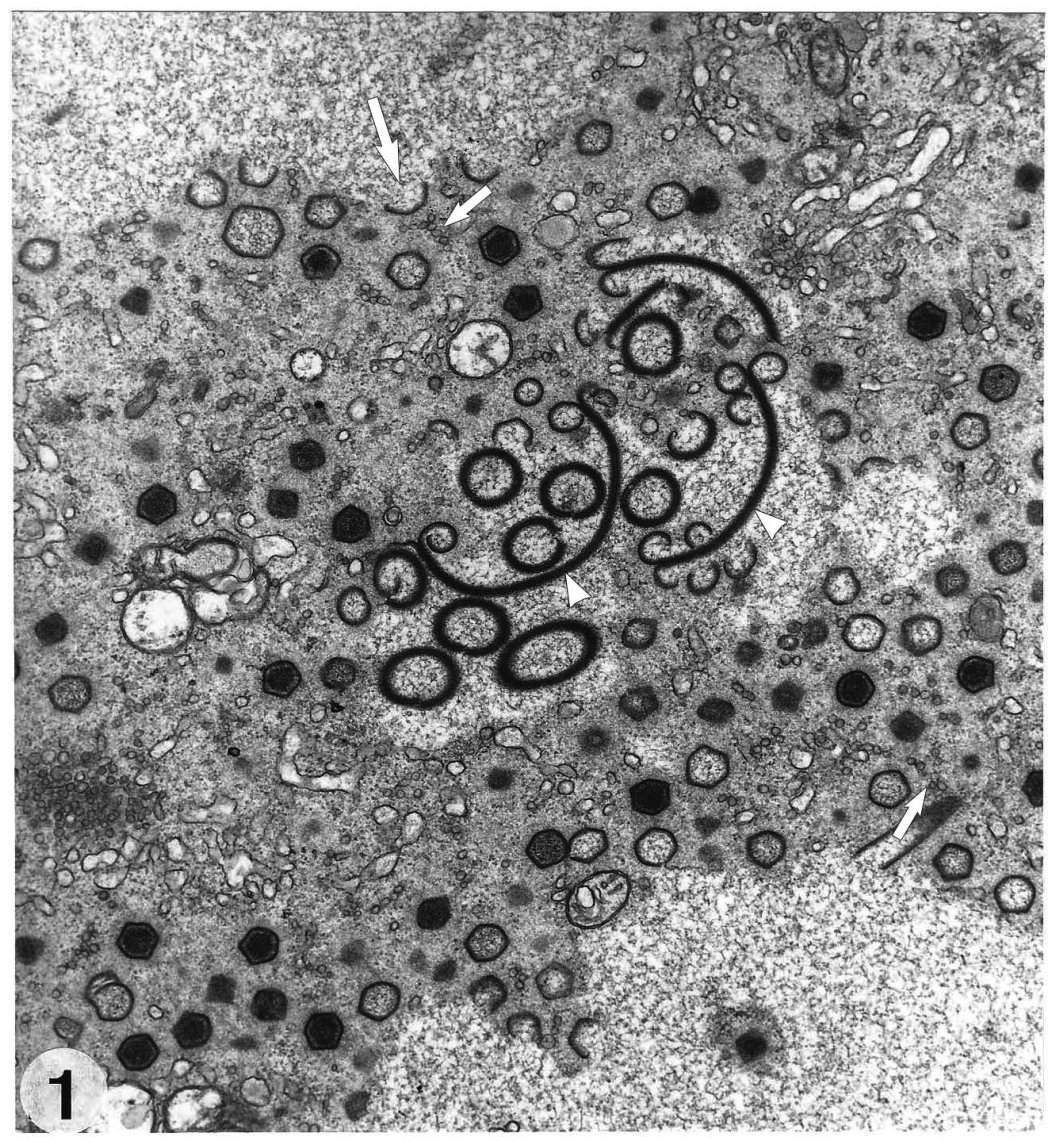

Fig. 1. EDIs (arrowheads) lying within the viral DNA; note partially formed capsids engulfing the DNA (large arrow), sER and strings of small vesicles (small arrows); $\times 8745$. Abbreviations are given in Table 1

sids, with an open side orientated toward the DNA-like matrix, appeared to be assembling at the interface. The DNA-like matrix appeared to pass into, or be engulfed by, the open ovoid to hexagonal capsids. Finally, the capsid appeared to close up with a strand of DNA at an opening at the vertex of the capsid (Fig. 2).

Irregular lysosome-like bodies (LLBs) with a very fine granular matrix, and dilated sER cisternae containing a similar matrix were common (Figs. 3 $\& 4)$. Also present were elliptical, rodlike or curved electron-dense inclusions (EDIs) that usually occurred within the VIB in association with lucent viral DNA at its periphery (Fig. 1), or away from the VIB among cell organelles (Fig. 5). At all of these sites, the EDIs enclosed viral DNA. infections in having many cell organelles around and enclosed by the long ribbon-like viral inclusion body (VIB). The matrix of the VIB resembled DNA (Figs. $1 \& 2$ ). At the periphery of the VIB, partially formed capsids appeared to enclose the VIB matrix (Fig. 1), which condensed to form the viral nucleoid, supporting identification of the VIB as viral DNA. The cytoplasm was rich in ribosomes, smooth endoplasmic reticulum (sER), developing capsids and strings or clusters of small vesicles that were often arrayed at the interface between the VIB and the surrounding area containing nucleocapsids (Fig. 1). Partially formed cap-

Figs. 2-4. Fig. 2. Empty capsid with an open apex (arrowhead), possibly to allow ingress of DNA, at the margin of the putative viral DNA $_{i} \times 12220$. Fig. 3 . LLBs (short arrow) and $\mathrm{sER}_{i} \times 9330$. Fig. 4. Nucleocapsids showing the clear area around the capsid (large arrow), sER and LLBs (short arrow); $\times 7560$. Abbreviations are given in Table 1
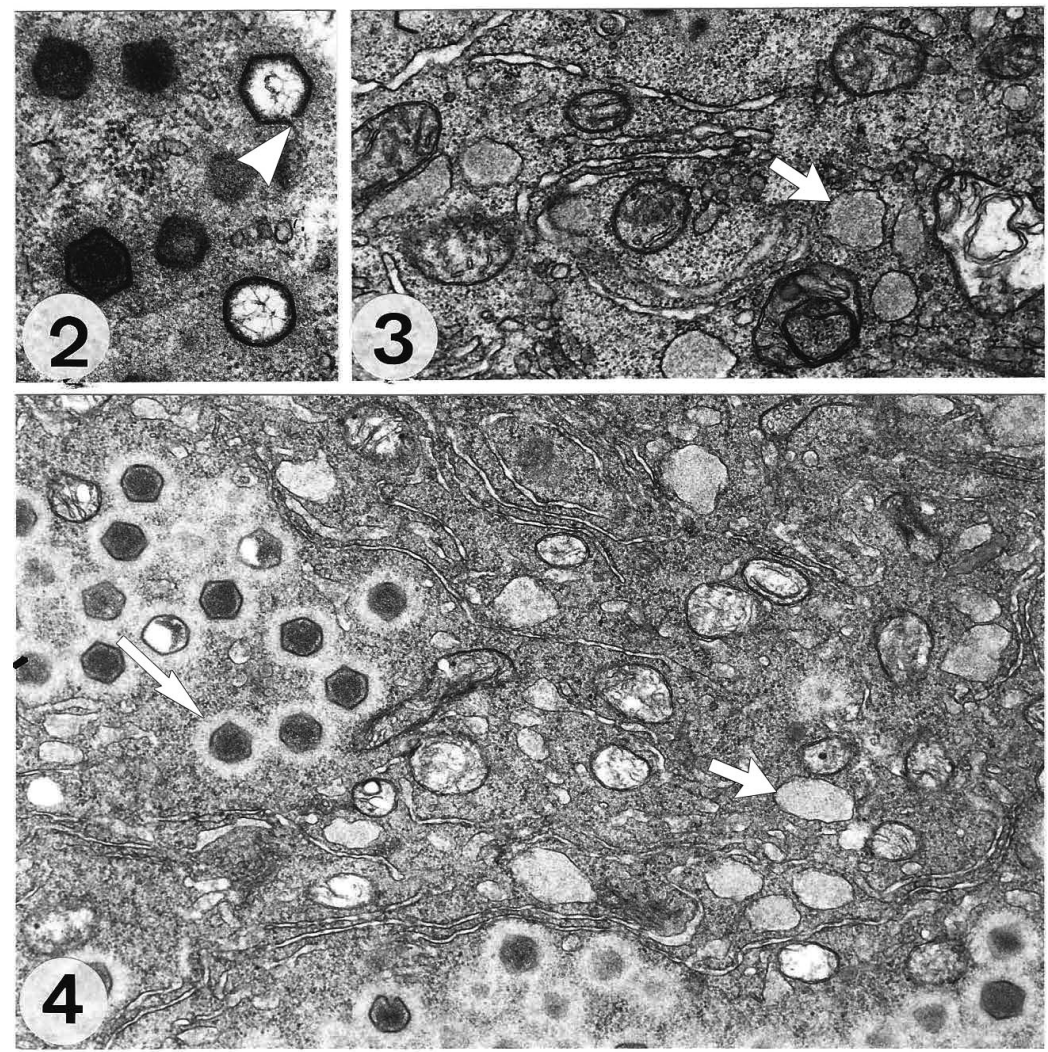


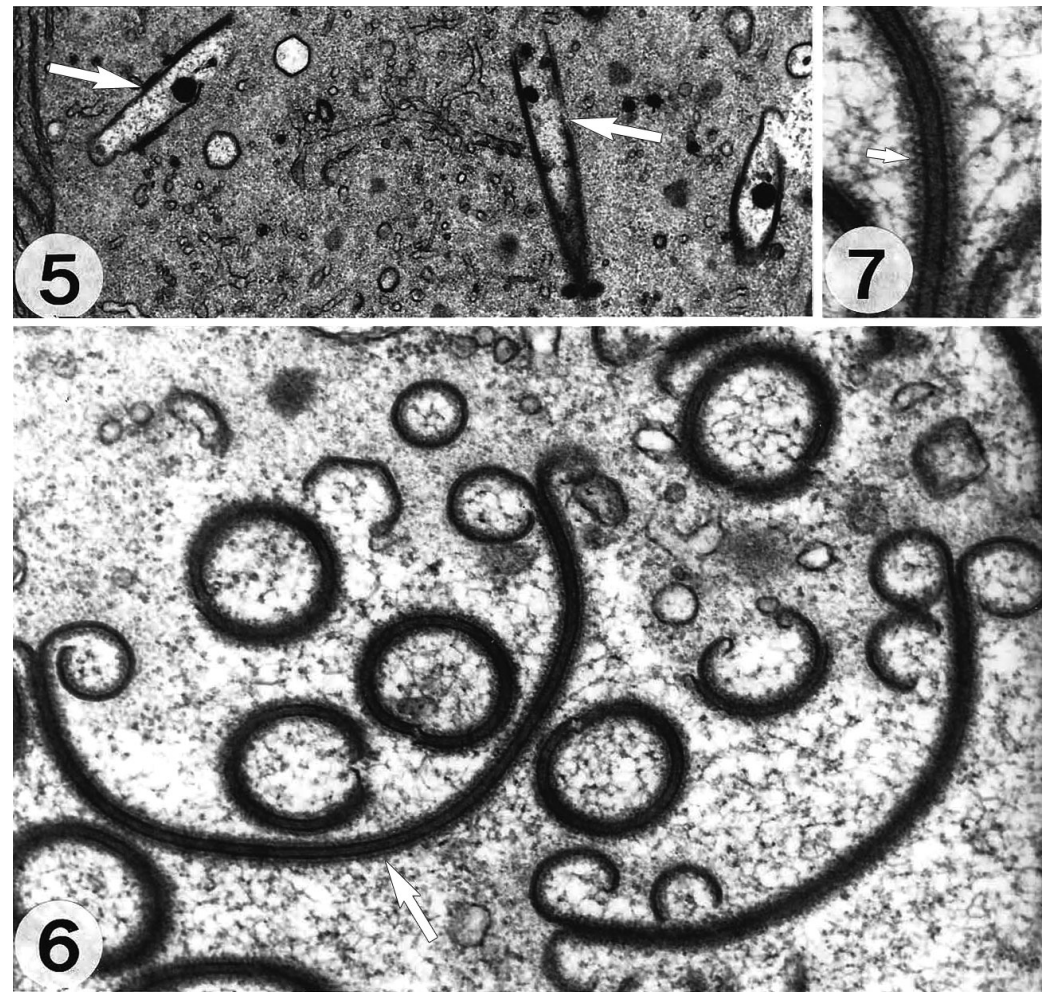

Figs. 5-7. Fig. 5. EDIs (arrows) enclosing DNA-like substance with $15 \mathrm{~nm}$ repeating subunits lying in the granular cytoplasm; $\times 7070$. Fig. 6. EDIs (arrow) showing the parallel dense lines, the dark homogenous matrix, surface repeating units and splits at the end $; \times 17740$. Fig. 7 . Detail of the repeating units (arrow) on the surface of the membrane $; \times 33330$. Abbreviations are given in Table 1

The walls of the EDIs contained 2 parallel dense lines separated by a dark homogenous matrix $30 \mathrm{~nm}$ wide (Fig. 6). The surface of the walls was dense and coated with small fibres, within which were uniform small repeating units $15 \mathrm{~nm}$ apart (Fig. 7). Curved EDIs split leaving 2 membranes each with a dense line, and the coated surface on one side (Fig. 6). These appeared to fragment and become more curved until they formed a circle with the coated surface internally, surrounding DNA (Fig. 6).
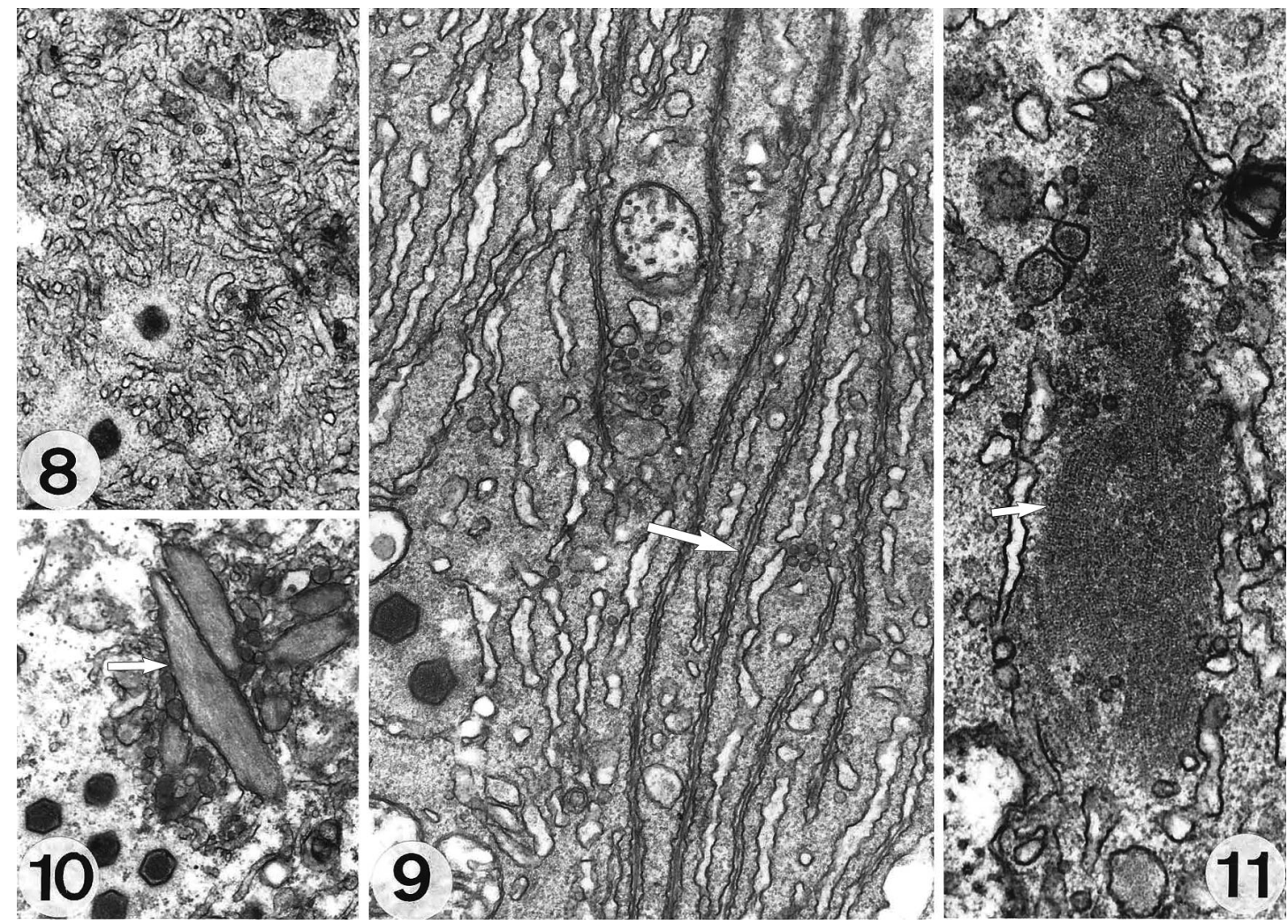

Figs. 8-11. Fig. 8. rsER $\times$ 7000. Fig. 9. Aligned profiles of tER (arrow) alternating with sER; $\times 9000$. Fig. 10. Granules with a fine fibrillar content (arrow) surrounded by rsER; $\times 7430$. Fig. 11 . Forming granule with a fine fibrillar/para-crystalline content (arrow) $\times 15000$. Abbreviations are given in Table 1 


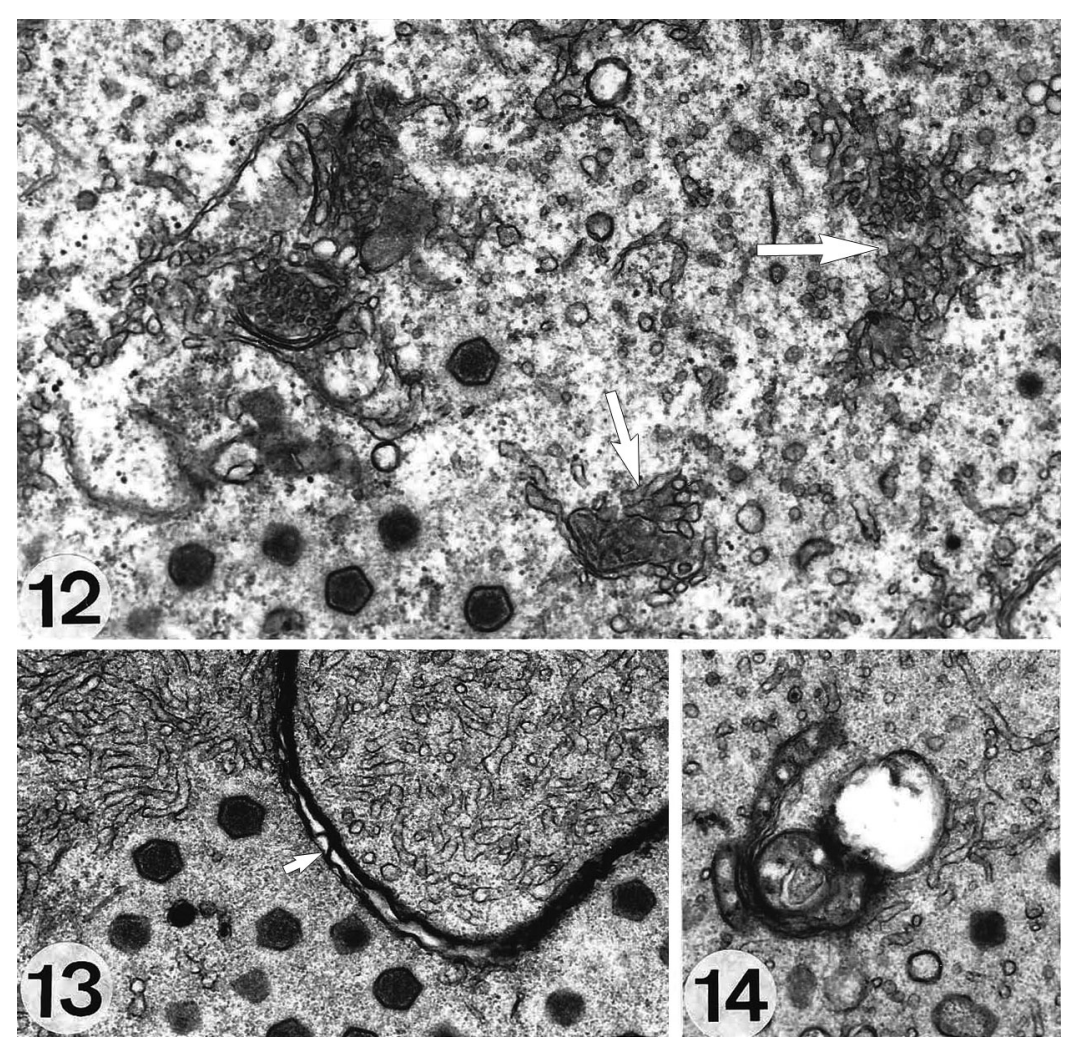

Figs. 12-14. Fig. 12. Golgi arrays (arrows) associated with small vesicles, rsER and LLBs $; \times \overline{8400 . ~ F i g . ~ 13 . ~ P r o f i l e ~ o f ~ s E R ~ c o n t a i n i n g ~ a ~ l o n g i t u d i n a l ~ s t r u c t u r e ~}$

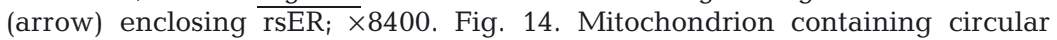
electron-lucent areas $; \times 73 \overline{25}$. Abbreviations are given in Table 1

(Fig. 3), or contained a circular electron-lucent area (Fig. 14).

The plasma membrane was very reticulated, ramifying into the surrounding hyaline capsule (Fig. 15). Endocytosis was not apparent. In presumably later infections, the plasma membrane disintegrated, leaving unenveloped virions free among the cellular debris next to the capsule (Fig. 16). Enveloped nucleocapsids were never observed, nor were they observed passing into or through cytoplasmic membranes, or budding from the plasma membrane. Collagen fibres, presumably from ensheathing fibrocytes, occurred among peripheral cellular debris (Fig. 16). At the late stage, the nucleus displayed faint chromatin and an irregular beaded nuclear membrane (Fig. 17). Around, and perhaps attached to, the nuclear membrane were many reticulated and beaded profiles of sER (Fig. 17) and mitochondria that appeared damaged (not shown), among a densely packed fine granular background.

Developing capsids adjacent to the DNA-like areas were hexagonal to

Away from the areas of capsidation were very large masses of reticulated sER (rsER) (Fig. 8), and very large parallel arrays of $\mathrm{SER}$, that sometimes alternated with aligned arrays of crinkled cisternae along which passed a uniformly wide $(20 \mathrm{~nm})$ thread-like structure (tER) (Fig. 9, and see Fig. 15). The rsER sometimes surrounded elongated granules with a fine fibrillar (Fig. 10) or para-crystalline content (Fig. 11). LLBs were common near rsER and sER (Figs. 3 \& 4). Multiple Golgi bodies were common, and often associated with large clusters of small vesicles, rsER and LLBs (Fig. 12). They were not observed between the large parallel arrays of sER. Some elongated profiles of sER contained a longitudinal structure resembling a unit membrane. These appeared to coil around and encircle some areas of cytoplasm lacking organelles or with small vesicles, rsER (Fig. 13), degenerating mitochondria and large vacuoles. They were electron-dense but resembled myelin-like figures or multiple lamellae. Mitochondria appeared normal, were vacuolated, had an internal circular to ovoid inclusion in a fine granular matrix surrounded by a unit membrane pentagonal or rounded, with an osmiophilic capsid and a thin layer of flocculent material on the internal capsid wall, connected to DNA-like threads (Fig. 2). Capsids and nucleocapsids had a halo comprising fine granular to fibrillar matter similar to that seen in LLBs and the elongated granules. These were interpreted as fibrils on the capsid (Fig. 4). Capsid dimensions (all measurements $\mathrm{nm}, \mathrm{n}=10$ ) were capsid 262-278 (vertex to vertex, v-v) $\times 216-249$ (face to face, f-f) to 340-362 (v-v) $\times 302-340(\mathrm{f}-\mathrm{f})$ with clear halo. In other nearby capsids the internal space was filled with osmiophilic granular material, 262-266 $(\mathrm{v}-\mathrm{v}) \times 216-240(\mathrm{f}-\mathrm{f})$ to $360-362 \times 319-340$ with fibrils, that appeared to condense, leaving a dense core and granular, but more lucent, space between the core and the capsid, 238-269 (v-v) $\times$ 204-231 (f-f) to $442-481 \times 365-483$ with fibrils (Fig. 2). Large paracrystalline arrays of nucleocapsids had a space of $180 \mathrm{~nm}$ between them, the spacing probably due to the external fibrillar layers (Fig. 18). Other than nucleocapsids, such arrays usually contained sparse ribosomes, and a few sER profiles (Fig. 18). Toward the apparent end of virogenesis, empty ovoid to 
hexagonal capsids, 269-315 (v-v) $\times$ 238-269 (f-f) to 385-462 × 327-385 with fibrils, were common around the lighter sparse DNA-like matrix.

\section{DISCUSSION}

Many of the features of the virus in parore are common to iridoviruses, such as VIBs, a perinuclear lucent viromatrix, encapsidation of DNA, icosahedral virions and paracrystalline arrays. Lysosomes have been reported from the viromatrix of a ranavirus infection of grouper (Chao et al. 2004). The entry of putative DNA into a nearly complete capsid (Fig. 2) has also been reported from grouper iridoviral infection (Qin et al. 2001). Damaged mitochondria (Fig. 14) also occur in lymphocystis disease virus (LCDV)-infected cells (Zhang et al. 1997, Paperna et al. 2001, Chao et al. 2004), and the convoluted or reticulated surface of LCDV-infected cells (Fig. 15) has been reported from flounder (Zhang et al. 2003). The bodies containing fibrils (Fig. 11) may be homologous with fibril-like elements in grouper virus (right of Fig. 10C in Chao et al. 2004) and in Rana grylio (Fig. 3A in Huang et al. 2006), and possibly peripherally in sturgeon (Adkinson et al. 1998), but not on virions. However, fibrils occur on LCDV virions (Zwillenberg \& Wolf 1968), appearing as a halo (Berthiaume et al. 1984), as was observed here.

Two other features are notable: (1) abundant sER including rsER and tER; and (2) EDIs. Abundant sER, whether in normal but swollen profiles (Figs. 3, 4 \& 9), reticulated sER (Figs. 8, 12 \& 13), tER (Figs. 9 \& 15), or strings of small vesicles (Figs. 1 \& 12), occurred throughout the viromatrix. In Fig. 12, Golgi at the left appears to be next to ballooned cisternae which may be Golgi cisternae or the trans-Golgi network (TGN), while at the bottom centre and at right there are similar ballooned clumps of rsER, suggest-

ing rsER derives from Golgi. There may be 4 compartments involved in NCLDV morphogenesis: ER, the Golgi, the ER Golgi intermediate compartment (ERGIC) and the TGN. The ERGIC and TGN are involved in membrane biogenesis and virogenesis in poxviruses (Schmelz et al. 1994, Risco et al. 2002, Moss 2015). Detailed studies on the monotypic asfarid NCLDV ASFV have shown that ER is involved in the formation of the lipid internal membrane between the core shell and capsid (Cobbold et al. 1996, Andrés et al. 1998, 2002, Rouiller et al. 1998, Epifano et al. 2006, Windsor et al. 2012, Salas \& Andrés 2013, Suarez et al. 2015), possibly due to col-

Figs. 17-18. Fig. 17. Irregular beaded nuclear membrane $(\text { arrow })_{i} \times 7700$. Fig. 18. Crystalline array of mature nucleocapsids $; ~ \times 5335$
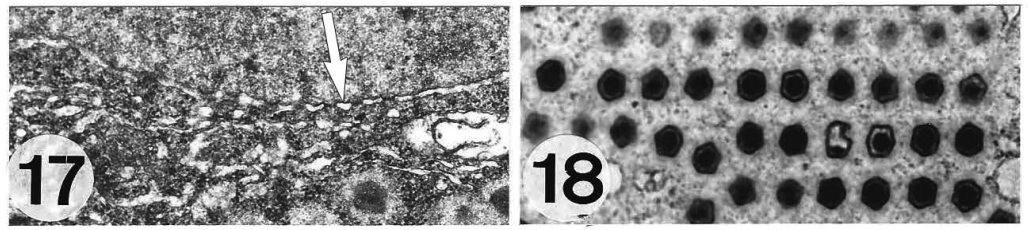
lapsed (Andrés et al. 1998) or ruptured (Suarez et al. 2015) ER cisternae pushing the 2 membranes together to form a unit-like membrane (Andrés et al. 1998). Most NCLDV viruses have a membrane that separates the nucleocapsid from the external capsid (Xiao \& Rossmann 2011), including LCDV (Heppell \& Berthiaume 1992), and host membranes probably serve as a scaffold to which capsid and shell proteins bind (Chinchar et al. 2011).

Despite this, ER is not commonly reported from piscine iridoviral infections. Small vesicles associated with encapsidation have been reported in LCDV infections (Fig. 3 in Howse \& Christmas 1971, Fig. 5 in Devauchelle et al. 1985). There is also a close association between the uncoating of frog virus 3 (FV3) virions and ER (Gendrault et al. 1981), and tubular structures involved in capsid formation in grouper iridovirus (Fig. 3A in Qin et al. 2001) may also be ER. Ranavirus virogenesis in frogs involves rER (Cunningham et al. 1996), and ER is mentioned in African lampeye Aplocheilichthys normani iridoviral infection (Sudthongkong et al. 2002).

The small vesicles in groups or lines next to developing capsids (Fig. 1, small arrows) that appear to derive from the rsER (Fig. 8) cannot be due to the angle at which associated rsER was sectioned, only if rsER formed the vesicles. The vesicles resemble in appearance, size and position the vesicles associated with the genesis of lipid membranes in vaccinia virus, and similarly in mimivirus, and possibly in NCLDVs (Suárez et al. 2013). In the present study, the detailed structure of these vesicles was not examined, but most appear to be closed vesicles. However, in vaccinia virus, vesicles of the same size are only observed as open when they are very close to the developing virion. Also, in vaccinia virus, markers show the origin of these vesicles from ER, as ultrastructurally shown from rsER here. The formation of the lipid layer between the core shell and capsid, as illustrated for WSIV (Watson et al. 1998), may be a unifying feature of NCLDVs.

The thread-like structures (tER), which were often abundant, were not observed to participate in virogenesis. While similar structures have not been reported from other iridovirids, the tER superficially resembles the zipper-like structures that form the lipid layer between the core shell and the capsid in ASFV (Fig. 6D in Andrés et al. 1998, Fig. 5G in Andrés et al. 2002, Fig. 1b,e in Windsor et al. 2012), in the presence of a dark central thread and parallel alignments (Fig. 7d,e in Windsor et al. 2012). However, zipper-like structures are aberrant structures (Rodríguez et al. 2004, Epifano et al. 2006, Salas \&
Andrés 2013), formed by rupture (Suarez et al. 2015) not collapse (Andrés et al. 1998) of ER, and they are not homologous with tER. Also, while tER occurred between profiles of swollen ER, they were not seen to derive from the ER.

The initially external $15 \mathrm{~nm}$ repeating units of the EDIs (Fig. 7), and their splitting down the middle and curling to form circular structures enclosing putative viral DNA (Figs. 1, $5 \&$ 7), have not been previously reported from the Iridoviridae. In forming the circular profiles, the $15 \mathrm{~nm}$ repeating units lie on the internal surface of tubular structures, possibly similar to the tubular structures from which capsids form in an iridovirus-like systemic infection of swordtails Pterophyllum scalare (Figs. 12 \& 13 in Paperna et al. 2001) and a ranavirus replicating in fish cells (Fig. 2B,C in Huang et al. 2006). Coiling structures and rodshaped bodies in replication of a grouper, probable ranavirus (Fig. 8D in Chao et al. 2004), are similar to structures in swordtails (Fig. 12 in Paperna et al. 2001) and ranavirus in the fish epithelioma papulosum cyprini cell line (Fig. 2C in Huang et al. 2006). While tubular inclusions are reported from the virogenic matrix of $P$. scalare with LCDV (Figs. 18 \& 19 in Paperna et al. 2001), they do not appear to be similar to EDIs. Virogenesis of a frog-pathogenic iridovirus involves parallel multiple enclosing arrays of rER (Figs. 10 \& 11 in Cunningham et al. 1996), unlike anything seen here. Similarly, in the grouper virus (Fig. 8A,B in Chao et al. 2004) and an LCDV virus of plaice Pleuronectes platessa (Fig. 4 in Peters \& Schmidt 1995), the virogenic stroma is ring-shaped, unlike in the present study. Plaice virus virogenesis was also associated with club-shaped bodies with a lucent core containing a chevron-like pattern not reported elsewhere (Fig. 5 in Peters \& Schmidt 1995).

Most NCLDV viruses have a membrane that separates the nucleocapsid from the external capsid (Xiao \& Rossmann 2011), including piscine iridoviruses (Bloch \& Larsen 1993, Qin et al. 2001) such as LCDV (Heppell \& Berthiaume 1992). The WSIV virion appears to have 4 dense layers surrounding the core, interpreted as an inner lipid membrane, a capsid and a capsid envelope (Watson et al. 1998). However, envelopment has not been observed during WSIV replication, and the 4 dense layers in Fig. 2D of Watson et al. (1998) could be interpreted as an inner double membrane (layers 2 and 3), and a capsid (layer 4 ), formed in the same way as ASFV virions. This interpretation is supported by the close association between virion formation and the large arrays of cisternae at 'assembly sites' (Fig. 2C in Watson et al. 1998). 
Table 2. Differential features within viral groups. ISKNV: infectious spleen and kidney necrosis virus; LCDV: lymphocystis disease virus; WSIV: white sturgeon iridovirus; GFV: goldfish virus; IIV: insect iridovirus

\begin{tabular}{|lccccccc|}
\hline Feature & Ranaviruses & ISKNV & LCDV & WSIV & GFV & IIV & This study \\
\hline Hyaline capsule & - & - & + & - & - & - & + \\
Surface folding of infected cells & - & - & + & - & - & - & + \\
Ribbon-like inclusion body & - & - & + & - & - & + & + \\
Organelles within inclusion & - & - & + & - & - & + & + \\
Capsids with fibrils & - & - & + & - & - & + & + \\
Very large crystalline arrays & - & - & + & + & - & + \\
Apoptosis & + & + & - & - & + & + \\
Budding & + & + & - & - & + & & + \\
\hline
\end{tabular}

LCDV virions are not known to bud through the plasma membrane; instead, the plasma membrane disintegrates with release of virions through cracks in the capsule (Spitzer et al. 1982, Colorni \& Diamant 1995). LCDVs are therefore unenveloped, which may be related to the possession of surface fibrils. Budding is common in ranaviruses (Hengstberger et al. 1993, Zupanovic et al. 1998, Qin et al. 2001, Majji et al. 2006, Weir et al. 2012, Ma et al. 2014), but small crystalline arrays occur which do not bud (Langdon et al. 1986, Ogawa et al. 1990, Hengstberger et al. 1993, Tapiovaara et al. 1998, Zupanovic et al. 1998, Zhang et al. 1999, Qin et al. 2001, 2003). Unenveloped virions in crystalline arrays of FV3 (Houts et al. 1974, Devauchelle et al. 1985) can enter susceptible cells by fusion of the internal lipid membrane of the capsid with the host cell plasma membrane (Houts et al. 1974, Gendrault et al. 1981). However, entry of FV3 enveloped virions is up to 150 -fold greater than entry of unenveloped virions (Braunwald et al. 1985). Ranaviruses may also infect adjacent cells by budding from one cell and at the same time being endocytosed by the adjacent cell (Granzow et al. 1997, Zhang et al. 1999). Insect iridoviruses may be taken up by phagocytosis (Webb et al. 1976). The bursting of LCDV-infected cells and release of virions onto surrounding cells may permit effective transmission (Spitzer et al. 1982). Virions of other iridoviruses may also bud through cytoplasmic membranes (Pozet et al. 1992), into cytoplasmic vesicles (Zhang et al. 1999), or through ER (Langdon et al. 1986). The capsid surface fibrils in LCDV and IIV may have a function in cell entry as the 2 groups that have big crystalline arrays and shed unenveloped virions.

It cannot be assumed that the virus reported here was an LCDV, as ranaviruses (Pozet et al. 1992, Bayley et al. 2013, Chinchar \& Waltzek 2014, George et al. 2015) and megalocytiviruses (Subramaniam et al.
2012, Waltzek et al. 2012) also infect fish, are very non-host specific (Mao et al. 1997, 1999, Hyatt et al. 2000, Bayley et al. 2013), and a single host genus such as grouper (Epinephalus) may be infected with ranavirus (Peng et al. 2015) and LCDV (Huang et al. 2015). Geographic occurrence rather than host group specificity may be as important in determining which host groups are infected (Mao et al. 1997, 1999, Hyatt et al. 2000, Bayley et al. 2013).

However, the virus reported here resembles LCDV in the restriction of infection to grape-like clusters on the skin (Dezfuli et al. 2012) and the presence of surface fibrils on mature virions (Berthiaume et al. 1984) (Table 2). Lymphocystiviruses are contained within a hyaline capsule (Howse 1972, Spitzer et al. 1982, Bowden et al. 1995, Sarasquete et al. 1998), and only cause chronic, non-lethal, non-invasive infection, unlike systemic iridoviral infections (ISKNV, WSIV). When LCDV and ranaviruses have the same tissue tropism, such as the dermis and the spleen, LCDV-infected cells are always encapsulated (Colorni \& Diamant 1995), whereas those of non-LCDV iridoviruses are not (Bloch \& Larsen 1993, Martinez-Picado et al. 1993). As cells infected by non-LCDV iridoviruses hypertrophy, they lose their plasma membrane folding, but in LCDV infection the plasma membrane becomes more folded and reticulated (Paperna et al. 1982, 1987). While a presumptive identification of LCDV may be correct, the lines or groups of small vesicles, abundant rsER, EDIs and large arrays of tER have not been previously reported from vertebrate-infecting members of the family Iridoviridae.

Acknowledgements. We thank Dr Cristina Suarez of the Electron Microscopy Core Facility of Heidelberg University, and Dr Maria Salas of the Centro de Biologia Molecular, Universidad Autonoma de Madrid, for kind provision of their papers. 


\section{LITERATURE CITED}

Adkinson MA, Cambre M, Hedrick RP (1998) Identification of an iridovirus in Russian sturgeon (Acipenser guldenstadi) from Northern Europe. Bull Eur Assoc Fish Pathol 18:29-32

> Andrés G, Garcia-Escudero R, Simón-Mateo C, Viñuela E (1998) African swine fever virus is enveloped by a twomembraned collapsed cisterna derived from endoplasmic reticulum. J Virol 72:8988-9001

Andrés G, Alejo A, Salas J, Salas ML (2002) African swine fever virus polyproteins pp220 and pp62 assemble into the core shell. J Virol 76:12473-12482

Bayley AE, Hill BJ, Feist SW (2013) Susceptibility of the European common frog Rana temporaria to a panel of ranavirus isolates from fish and amphibian hosts. Dis Aquat Org 103:171-183

> Berthiaume L, Alain R, Robin J (1984) Morphology and ultrastructure of lymphocystis disease virus, a fish iridovirus, grown in tissue culture. Virology 135:10-19

> Bloch B, Larsen JL (1993) An iridovirus-like agent associated with systemic infection in cultured turbot Scophthalmus maximus fry in Denmark. Dis Aquat Org 15: 235-240

Bowden RA, Oestmann DJ, Lewis DH, Frey MS (1995) Lymphocystis in red drum. J Aquat Anim Health 7:231-235

> Braunwald J, Nonnenmacher H, Tripier-Darcy F (1985) Ultrastructural and biochemical study of frog virus 3 uptake by BHK-21 cells. J Gen Virol 66:283-293

> Chao CB, Chen CY, Lai YY, Lin CS, Huang HT (2004) Histological, ultrastructural, and in situ hybridization study on enlarged cells in grouper Epinephelus hybrids infected by grouper iridovirus in Taiwan (TGIV). Dis Aquat Org 58:127-142

> Chinchar VG (2002) Ranaviruses (family Iridoviridae): emerging cold-blooded killers. Brief review. Arch Virol 147:447-470

Chinchar VG, Waltzek TB (2014) Ranaviruses: not just for frogs. PLOS Pathog 10:e1003850

> Chinchar VG, Hyatt A, Miyazaki T, Williams T (2009) Family Iridoviridae: poor relations no longer. Curr Top Microbiol Immunol 328:123-170

Chinchar VG, Yu KH, Jancovich JK (2011) The molecular biology of frog virus 3 and other iridoviruses infecting cold-blooded vertebrates. Viruses 3:1959-1985

Clouthier SC, VanWalleghem E, Copeland S, Klassen C, Hobbs G, Nielsen O, Anderson ED (2013) A new species of nucleo-cytoplasmic large DNA virus (NCLDV) associated with mortalities in Manitoba lake sturgeon Acipenser fulvescens. Dis Aquat Org 102:195-209

Cobbold C, Whittle JT, Wileman T (1996) Involvement of the endoplasmic reticulum in the assembly and envelopment of African swine fever virus. J Virol 70:8382-8390

Colorni A, Diamant A (1995) Splenic and cardiac lymphocystis in the red drum Sciaenops ocellatus (L.). J Fish Dis 18:467-471

Cunningham AA, Langton TES, Bennett PM, Lewin JF, Drury SEN, Gough RE, Macgregor SK (1996) Pathological and microbiological findings from incidents of unusual mortality of the common frog (Rana temporaria). Philos Trans R Soc Lond B Biol Sci 351:1539-1557

$>$ Devauchelle G, Stoltz DB, Darcy-Tripier F (1985) Comparative ultrastructure of iridoviridae. Curr Top Microbiol Immunol 116:1-21
Dezfuli BS, Lui A, Giari L, Castaldelli G, Mulero V, Noga EJ (2012) Infiltration and activation of acidophilic granulocytes in skin lesions of gilthead seabream, Sparus aurata, naturally infected with lymphocystis disease virus. Dev Comp Immunol 36:174-182

Epifano C, Krijnse-Locker J, Salas ML, Salas J, Rodriguez JM (2006) Generation of filamentous instead of icosahedral particles by repression of African swine fever virus structural protein pB438L. J Virol 80:11456-11466

> Gendrault JL, Steffan AM, Bingen A, Kirn A (1981) Penetration and uncoating of frog virus 3 (FV3) in cultured rat Kupffer cells. Virology 112:375-384

George MR, John KR, Mansoor MM, Saravanakumar R, Sundar P, Pradeep V (2015) Isolation and characterization of a ranavirus from koi, Cyprinus carpio L., experiencing mass mortalities in India. J Fish Dis 38:389-403

> Granzow H, Weiland F, Fichtner D, Enzmann PJ (1997) Studies of the ultrastructure and morphogenesis of fish pathogenic viruses grown in cell culture. J Fish Dis 20: $1-10$

- Hengstberger SG, Hyatt AD, Speare R, Coupar BEH (1993) Comparison of epizootic haematopoietic necrosis and Bohle iridoviruses, recently isolated Australian iridoviruses. Dis Aquat Org 15:93-107

> Heppell J, Berthiaume L (1992) Ultrastructure of lymphocystis disease virus (LDV) as compared to frog virus 3 (FV3) and chilo iridescent virus (CIV): effects of enzymatic digestions and detergent degradations. Arch Virol 125: $215-226$

> Houts GE, Gravell M, Granoff A (1974) Electron microscopic observations on early events of frog virus 3 replication. Virology 58:589-594

> Howse HD (1972) Snook (Centropomus: Centropomidae): new host for lymphocystis, including observations on the ultrastructure of the virus. Am Midl Nat 88:476-479

Howse HD, Christmas JY (1971) Observations on the ultrastructure of lymphocystis virus in the Atlantic croaker, Micropogon undulatus (Linneaus). Virology 44: 211-214

> Huang XH, Huang YH, Yuan XP, Zhang QY (2006) Electron microscopic examination of the viromatrix of Rana grylio virus in a fish cell line. J Virol Methods 133:117-123

> Huang X, Huang Y, Xu L, Wei S, Ouyang Z, Feng J, Qin Q (2015) Identification and characterization of a novel lymphocystis disease virus isolate from cultured grouper in China. J Fish Dis 38:379-387

Hyatt AD, Gould AR, Zupanovic Z, Cunningham AA and others (2000) Comparative studies of piscine and amphibian iridoviruses. Arch Virol 145:301-331

Inouye K, Yamano K, Maelo Y, Nakajima K, Matsuoka M, Wada Y, Sorimachi M (1992) Iridovirus infection of cultured red sea bream, Pagrus major. Fish Pathol 27:19-27

Kurita J, Nakajima K (2012) Megalocytiviruses. Viruses 4: 521-538

> Langdon JS, Humphrey JD, Williams LM, Hyatt AD, Westbury HA (1986) First virus isolation from Australian fish: an iridovirus-like pathogen from redfin perch, Perca fluviatilis L. J Fish Dis 9:263-268

Ma J, Zeng L, Zhou Y, Jiang N and others (2014) Ultrastructural morphogenesis of an amphibian iridovirus isolated from Chinese giant salamander (Andrias davidianus). J Comp Pathol 150:325-331

> Majji S, LaPatra S, Long SM, Sample R, Bryan L, Sinning A, Chinchar VG (2006) Rana catesbeiana virus Z (RCV-Z): a novel pathogenic ranavirus. Dis Aquat Org 73:1-11 
Mao J, Hedrick RP, Chinchar VG (1997) Molecular characterization, sequence analysis and taxonomic position of newly isolated fish iridoviruses. Virology 229:212-220

Mao J, Green DE, Fellers G, Chinchar VG (1999) Molecular characterization of iridoviruses isolated from sympatric amphibians and fish. Virus Res 63:45-52

Martinez-Picado J, Blanch AR, Jofre J (1993) Iridovirus-like particles associated with nodular skin lesions and vesicles in Parapocryptes serperaster. J Aquat Anim Health 5:148-151

Moss B (2015) Poxvirus membrane biogenesis. Virology 479480:619-626

> Ogawa M, Ahne W, Fischer-Scherl T, Hoffmann RW, Schlotfeldt HJ (1990) Pathomorphological alterations in sheatfish fry Silurus glanis experimentally infected with an iridovirus-like agent. Dis Aquat Org 9:187-191

Paperna I, Sabnai I, Colorni A (1982) An outbreak of lymphocystis in Sparus aurata L. in the Gulf of Aqaba, Red Sea. J Fish Dis 5:433-437

> Paperna I, Ventura TM, de Matos AP (1987) Lymphocystis infection in snakeskin gourami, Trichogaster pectoralis (Regan), (Anabantidae). J Fish Dis 10:11-19

> Paperna I, Vilenkin M, Alves de Matos AP (2001) Iridovirus infections in farm-reared tropical ornamental fish. Dis Aquat Org 48:17-25

> Pearce M, Humphrey JD, Hyatt AD, Williams LM (1990) Lymphocystis disease in captive barramundi Lates calcarifer. Aust Vet J 67:144-145

Peng C, Ma H, Su Y, Wen W, Feng J, Guo Z, Qiu L (2015) Susceptibility of farmed juvenile giant grouper Epinephalus lanceolatus to a newly isolated grouper iridovirus (genus Ranavirus). Vet Microbiol 177:270-279

$>$ Peters N, Schmidt W (1995) Formation and disintegration of virions in lymphocystis cells of plaice Pleuronectes platessa. Dis Aquat Org 21:109-113

> Piégu B, Asqari S, Bideshi D, Federici BA, Bigot Y (2015) Evolutionary relationships of iridoviruses and divergence of ascoviruses from invertebrate iridoviruses in the superfamily Megavirales. Mol Phylogenet Evol 84: $44-52$

> Pozet F, Morand M, Moussa A, Torhy C, de Kinkelin P (1992) Isolation and preliminary characterization of a pathogenic icosahedral deoxyribovirus from the catfish Ictalurus melas. Dis Aquat Org 14:35-42

Qin QW, Lam TJ, Sin YM, Shen H, Chang SF, Ngoh GH, Chen CL (2001) Electron microscopic observations of a marine fish iridovirus isolated from brown-spotted grouper, Epinephalus tauvina. J Virol Methods 98: $17-24$

Qin QW, Chang SF, Ngoh-Lim GH, Gibson-Kueh S, Shi C, Lam TJ (2003) Characterization of a novel ranavirus isolated from grouper Epinephelus tauvina. Dis Aquat Org 53:1-9

Risco C, Rodriguez JR, López-Iglesias C, Carrascosa JL, Esteban M, Rodriguez D (2002) Endoplasmic reticulumGolgi intermediate compartment membranes and vimentin filaments participate in vaccinia virus assembly. J Virol 76:1839-1855

Rodríguez JM, Garcia-Escudero R, Salas ML, Andrés G (2004) African swine fever virus structural protein p54 is essential for the recruitment of envelope precursors to assembly sites. J Virol 78:4299-4313

Rouiller I, Brookes SM, Hyatt AD, Windsor M, Wileman T (1998) African swine fever virus is wrapped by the endoplasmic reticulum. J Virol 72:2373-2387
Salas ML, Andrés G (2013) African swine fever virus morphogenesis. Virus Res 173:29-41

Sarasquete C, Gonzalez de Canales ML, Arellano J, Perez-Prieto S, Garcia-Rosado E, Borrego JJ (1998) Histochemical study of lymphocystis disease in skin of gilthead sea bream, Sparus auratus L. Histol Histopathol 13:37-45

Schmelz M, Sodeik B, Ericsson M, Wolffe EJ, Shida H, Hiller G, Griffiths G (1994) Assembly of vaccinia virus: the second wrapping cisterna is derived from the trans Golgi network. J Virol 68:130-147

Spitzer RH, Koch EA, Reid RB, Downing SW (1982) Metabolic-morphologic characteristics of the integument of teleost fish with mature lymphocystis nodules. Cell Tissue Res 222:339-357

Sriwanayos P, Francis-Floyd R, Stidworthy MF, Petty BD, Kelley K, Waltzek TB (2013) Megalocytivirus infection in orbiculate batfish Platax orbicularis. Dis Aquat Org 105: $1-8$

Suárez C, Welsch S, Chlanda P, Hagen W and others (2013) Open membranes are the precursors for assembly of large DNA viruses. Cell Microbiol 15:1883-1895

Suarez C, Andres G, Kolovou A, Hoppe S, Salas ML, Walther P, Krijnse Locker J (2015) African swine fever virus assembles a single membrane derived from rupture of the endoplasmic reticulum. Cell Microbiol 17: 1683-1698

> Subramaniam K, Shariff M, Omar AR, Hair-Bejo M (2012) Megalocytivirus infection in fish. Rev Aquacult 4: 221-233

Sudthongkong C, Miyata M, Miyazaki T (2002) Iridovirus disease in two ornamental tropical freshwater fishes: African lampeye and dwarf gourami. Dis Aquat Org 48: 163-173

> Tanaka M, Yoshimizu M, Kusakari M, Kimura T (1984) Lymphocystis disease in kurosoi Sebastes schlegeli and hirame Paralichthys olivaceus in Hokkaido, Japan. Bull Jpn Soc Sci Fish 50:37-42 (in Japanese)

Tapiovaara H, Olesen NJ, Lindén J, Rimaila-Pärnänen E, von Bonsdorff $\mathrm{CH}$ (1998) Isolation of an iridovirus from pike-perch Stizostedion lucioperca. Dis Aquat Org 32: 185-193

> Waltzek TB, Marty GD, Alfaro ME, Bennett WR and others (2012) Systemic iridovirus from threespine stickleback Gasterosteus aculeatus represents a new megalocytivirus species (family Iridoviridae). Dis Aquat Org 98: 41-56

> Watson LR, Groff JM, Hedrick RP (1998) Replication and pathogenesis of white sturgeon iridovirus (WSIV) in experimentally infected white sturgeon Acipenser transmontanus juveniles and sturgeon cell lines. Dis Aquat Org 32:173-184

> Webb SR, Paschke JD, Wagner GW, Campbell WR (1976) Pathology of mosquito iridescent virus of Aedes taeniorhynchus in cell cultures of Aedes aegypti. J Invertebr Pathol 27:27-40

Weir RP, Moody NJG, Hyatt AD, Crameri S, Voysey R, Pallister J, Jerrett IV (2012) Isolation and characterisation of a novel Bohle-like virus from two frog species in the Darwin rural area, Australia. Dis Aquat Org 99:169-177

> Whittington RJ, Becker JA, Dennis MM (2010) Iridovirus infections in finfish - critical review with emphasis on ranaviruses. J Fish Dis 33:95-122

Windsor M, Hawes P, Monaghan P, Snapp E, Salas ML, Rodriguez JM, Wileman T (2012) Mechanism of collapse 
of endoplasmic reticulum cisternae during African swine fever virus infection. Traffic 13:30-42

Xiao C, Rossmann MG (2011) Structures of giant icosahedral eukaryotic dsDNA viruses. Curr Opin Virol 1:101-109

> Yan XY, Wu ZH, Jian JC, Lu YS, Sun XQ (2011) Analysis of the genetic diversity of the lymphocystis virus and its evolutionary relationship with its hosts. Virus Genes 43: 358-366

Zhang Y, Guo Q, Wu Z (1997) Ultrastructural histopathological study on lymphocystis of kelp bass, Epinephelus moara. Oceanol Limnol Sin 28:406-410

Zhang QY, Li ZQ, Gui JF (1999) Studies on morphogenesis

Editorial responsibility: Mark Crane,

Geelong, Victoria, Australia and cellular interactions of Rana grylio virus in an infected fish cell line. Aquaculture 175:185-197

Zhang QY, Ruan HM, Li ZQ, Yuan XP, Gui JF (2003) Infection and propagation of lymphocystis virus isolated from the cultured flounder Paralichthys olivaceus in grass carp cell lines. Dis Aquat Org 57:27-34

Zupanovic Z, Musso C, Lopez G, Louriero CL, Hyatt AD, Hengstberger S, Robinson AJ (1998) Isolation and characterization of iridoviruses from the giant toad Bufo marinus in Venezuela. Dis Aquat Org 33:1-9

Zwillenberg LO, Wolf K (1968) Ultrastructure of lymphocystis virus. J Virol 2:393-399

Submitted: January 28, 2016; Accepted: August 3, 2016

Proofs received from author(s): August 27, 2016 